\title{
Size Structure of Phytoplankton Community and its Response to Environmental Factors in Spring and Summer in Xiamen Bay, China
}

\author{
Ting-ting FU ${ }^{1,2, a}$, Bao-hong $\mathrm{CHEN}^{1, \mathrm{~b}, *}$, Wei-dong $\mathrm{JI}^{1, \mathrm{c}}$, Wen-feng $\mathrm{CHEN}^{1, \mathrm{~d}}$, Hui $\mathrm{LIN}^{1, \mathrm{e}}$, Yong $\mathrm{LUO}^{1, \mathrm{f}}$ and $\mathrm{Kang}$ \\ $\mathrm{WANG}^{1, \mathrm{~g}}$ \\ ${ }^{1}$ Laboratory of marine chemistry and environmental monitoring technology, Third Institute of Oceanography, State Oceanic \\ Administration, Xiamen, China \\ ${ }^{2}$ Fujian institute of oceanography, Xiamen, China \\ afutingting@tio.org.cn, bchenbaohong@tio.org.cn, ${ }^{\mathrm{c}}$ jiweidong@ti o.org.cn, ${ }^{\mathrm{d}}$ chenwenfeng@tio.org.cn, ${ }^{\mathrm{e}}$ linhui@tio.org.cn \\ fluoyong@tio.org.cn
}

\begin{abstract}
Environmental characteristics and phytoplankton size structure were investigated during spring and summer cruises in 2015 in Xiamen Bay of China. The distribution of total Chlorophyll $a(\mathrm{Chla})$ showed a seasonal and spatial variation. In surface water, total Chla concentration increased from west to east in spring, while it showed the highest value in nutrient-rich West water in summer. Total Chla concentration was higher in summer than in spring. Nano-phytoplankton dominated in this study area. In spring, nano- proportion was the highest in the Jiu'long River Estuary and showed a positive correlation with nutrient in surface water. Micro- and pico- proportion were the highest in Da'deng water. In summer, nano- proportion was higher in most stations than that in spring, and micro- was on the contrary. And pico- proportion was the highest in West water. The distribution of each size-fractionated phytoplankton in bottom water was almost similar with that of surface water in these two cruises. Compared with historical data, nanoproportion increased and micro- decreased. Based on correlations between size-fractionated phytoplankton and environmental factors, nutrient availability and temperature played significant roles on size structure of phytoplankton community. Results suggested that size structure of phytoplankton community probably turned to be smaller with environmental factors changes especially eutrophication and climate warming in Xiamen Bay.
\end{abstract}

Keyword-phytoplankton; Chla; eutrophication; relationship; Bay

\section{INTRODUCTION}

As mainly marine primary producer, phytoplankton has a significant ecological function, affecting the biogenic carbon fate and food webs in pelagic ecosystem [1], [2]. Additionally, phytoplankton is usually employed as an indicator of eutrophication [3]. Phytoplankton community structure largely determines the trophic organization of pelagic ecosystem and thus the efficiency with which organic matter produced by photosynthesis is channeled towards upper trophic levels or exported to the ocean's interior [4], [5], [6]. Studies of phytoplankton community from size-based viewpoint provide some important information of phytoplankton dynamics in marine ecosystem [7], [8].
It was generally considered that smaller phytoplankton was typical of oligotrophic system, while phytoplankton dominated by larger ones in nutrient enrichment coastal areas [8], [9], [10], [11]. However, some research results are in contrast with this general principle. For instance, Jiao et al. (2001) suggested that net-sampling phytoplankton $(>69 \mu \mathrm{m})$ Chla concentration had a long-term decreasing trend with increasing DIN concentrations in Jiaozhou Bay of China [12]. Zingone et al. (2011) reported that a high phytoplankton biomass was coupled with small-sized cells in the Magellan Straits [13]. Suikkanen et al. (2013) reported that phytoplankton communities have shifted towards a food web structure with smaller sized organisms in warming and eutrophication Baltic Sea [14]. Therefore, it is interrogative that how environmental changes especially eutrophication influence size structure of phytoplankton community in coastal areas. Besides nutrient, temperature, salinity, irradiance, grazing pressure and physical process are also important factors affecting size structure of phytoplankton community in different waters [15], [16], [17], [18]. For instance, micro-phytoplankton biomass increases with latitude, and pico-phytoplankton plays a more important role in tropical and subtropical oceanic water [19], [20], [21]. When irradiance is weak with nutrient-rich water, smaller phytoplankton showed faster growth than that of larger ones [22].

Xiamen Bay is a semi-enclosed water body situated in the west of Taiwan Strait, with large size and strong regularly semidiurnal tide. The Jiu'long River, as the second largest river in Fujian province, flows into Xiamen Bay with an annual average water discharge of about $13.0 \times 10^{9} \mathrm{~m}^{3}$ [23]. Hydrologic environment in Xiamen Bay is mainly affected by tide system of the Taiwan Strait, runoff of the Jiu'long River and Min-Zhe coastal current [24], [25]. Eutrophication phenomenon has become a severe problem in the bay with population pressure increased over 20 years [26], similar to what happened in the Jiaozhou Bay [12], [27] and the Pearl River Estuary [28], [29]. Meanwhile, phytoplankton community is dominated by more nano-dominant species and less micro-dominant species in these years by identifying 
phytoplankton species under microscope observation in these three water areas [16] [25], [30]. Some researchers have investigated the changes of size structure of phytoplankton community and nutrient concentration in Xiamen Bay [31], [32], [33], [34]. Researches on seasonal and spatial distribution features of phytoplankton size structure and response of phytoplankton to environmental factors in different seasons have not been reported yet. Therefore, the purpose of this paper is to (1) investigate the seasonal and spatial distribution of total and size-fractionated phytoplankton biomass in Xiamen Bay, (2) determine the major environmental factors controlling their seasonal variation, (3) and explore if eutrophication is the main factor of causing miniaturization of phytoplankton community.

\section{MATERIAL AND METHODS}

\section{A. Sampling Stations}

The samples were collected at 16 stations both in surface and bottom water in Xiamen Bay during spring (in May) and summer (in August) cruises in 2015 $\left(24.4^{\circ} \mathrm{N}-24.7^{\circ} \mathrm{N}\right.$ and $\left.117.9^{\circ} \mathrm{E}-118.4^{\circ} \mathrm{E}\right)$ (Fig. 1). Water samples were conducted vertically in accordance with the depths. When the depth was $\leq 5 \mathrm{~m}$, surface water $(0.5 \mathrm{~m})$ was collected. When the depth was $\geq 5 \mathrm{~m}$, surface and bottom water were collected. In spring cruise, only surface water samples were collected in Station 2, 11-12, 14 and 16, because of the shallow water depth. According to salinity changes [34], Xiamen Bay can be divided into five parts: West water (Station 1-4), Jiu'long River Estuary (Station 5-7), East water (Station 8-10), Tong'an water (Station 11-13) and Da'deng water (Station 14-16).

\section{B. Environmental Factors}

Temperature and salinity were recorded in situ with a Conductivity- Temperature-Depth (CTD nke STPS100-PR). $500 \mathrm{~mL}$ water samples for dissolved inorganic nutrient (nitrite, nitrate, ammonium, phosphate and silicate) were filtered through $0.45 \mu \mathrm{m}$ cellulose acetate membrane and conserved at $0^{\circ} \mathrm{C}$, measured by 7230 spectrophotometer within 24 hours.

\section{Size-fractionated Chla}

Phytoplankton community could be divided into three classes: micro- $(>20 \mu \mathrm{m})$, nano- $(2 \mu \mathrm{m}-20 \mu \mathrm{m})$ and picophytopankton $(<2 \mu \mathrm{m})$ [35]. Water samples were firstly filtered through $20 \mu \mathrm{m}$ mesh netting via gravity. Filtrates were then sequentially filtered through $2 \mu \mathrm{m}$ and $0.2 \mu \mathrm{m}$ Polycarbonate Nuclepore under low vacuum pressure $(<100 \mathrm{~mm} \mathrm{Hg})$. Chla retained by the $20 \mu \mathrm{m}$ filters was considered micro-phytoplankton biomass, and that retained by the $2 \mu \mathrm{m}$ and $0.2 \mu \mathrm{m}$ filters constituted the nano- and pico-phytoplankton fractions, respectively. To determine total Chla concentration, $500 \mathrm{~mL}$ water sample was directly filtered through $0.2 \mu \mathrm{m}$ Polycarbonate Nuclepore. Filters were wrapped in aluminium foil and stored in liquid nitrogen before further processing. The Chla concentration was extracted in $10 \mathrm{~mL}$ of $90 \%$ acetone under dim light conditions at $-20^{\circ} \mathrm{C}$ for $14 \mathrm{~h}-24 \mathrm{~h}$, then the fluorescence was measured both before and after acidification with $10 \%$ hydrochloric acid using a Turner Designs fluorometer [36].

\section{Index of Phytoplankton Size Structure}

In order to address the relationships between phytoplankton size structure and its geographical distribution, a parameter called 'size index', proposed by Bricaud et al. (2004) was adopted [37]. Size index (abbreviated as SI) was derived by attributing a central size value to each size class (1,5 and $50 \mathrm{~mm}$ for pico-, nanoand micro-phytoplankton, respectively) and weighing this value by the proportion of the corresponding class. SI was calculated by the following formula: SI $(\mu \mathrm{m})=\{1 \times(\%$ pico- phytplankton $)+5 \times(\%$ nano- phytoplankton $)+50 \times(\%$ micro- phytplankton) $\} / 100$. Though size index is only a very rough indicator of the phytoplankton community, it can provide a single parameter to character the size structure.

\section{E. Statistical Analysis}

Correlation analysis was performed with SPSS statistics 20 to obtain a matrix of Pearson's correlation coefficients between size fractionated phytoplankton and environmental variables. The distributions of all parameters were generated by Surfer 11.0 (Golden, Greensboro, NC, USA).

\section{RESULTS}

\section{A. Environmental Variables}

Seasonal and spatial distribution of temperature, salinity and nutrient were showed in Fig. 2. In spring, temperature in surface and bottom water decreased gradually from northwest to southeast, with the highest value in West water (Fig. 2A). Salinity increased from west to east both in surface and bottom water. Since heavily influenced by freshwater from Jiu'long River runoff in surface water, salinity showed the lowest value in the Jiu'long River Estuary (Fig. 2B). The mean of temperature in surface water was little higher than that in bottom water $\left(25.2^{\circ} \mathrm{C}\right.$ and $24.8^{\circ} \mathrm{C}$ respectively), while salinity was opposite (30.14 and 31.62 respectively).

In surface water, the distribution of nutrient concentration was closely related to that of salinity. DIN concentration was $0.049 \mathrm{mg} / \mathrm{L}-1.159 \mathrm{mg} / \mathrm{L}$ (with the mean of $0.596 \mathrm{mg} / \mathrm{L}$ ), decreasing from west to east, which was opposite to the distribution of salinity. The highest value appeared in West water (Fig. 2C, Table 1). $\mathrm{PO}_{4}{ }^{3-}-\mathrm{P}$ concentration revealed the similar spatial distribution pattern with DIN concentration (Fig. 2D). $\mathrm{PO}_{4}{ }^{3-}-\mathrm{P}$ concentration was $0.003 \mathrm{mg} / \mathrm{L}-0.076 \mathrm{mg} / \mathrm{L}$, with the mean of $0.032 \mathrm{mg} / \mathrm{L}$. $\mathrm{SiO}_{3}{ }^{2-}-\mathrm{Si}$ concentration was $0.061 \mathrm{mg} / \mathrm{L}$ $2.167 \mathrm{mg} / \mathrm{L}$, decreasing from west to east, and the highest mean appeared in the Jiu'long River Estuary (Fig. 2E, Table 1). In bottom water, table 1 showed that DIN, $\mathrm{PO}_{4}{ }^{3-}-\mathrm{P}$ and $\mathrm{SiO}_{3}{ }^{2-}-\mathrm{Si}$ concentration was lower than those in surface water. The spatial distribution of nutrient concentrations showed similar trend to those in surface water. 
Consequently, two distinct ecological conditions were found in the spring, scilicet nutrient-rich and low salinity coastal area and low nutrient and high salinity water region.

In summer, temperature and salinity showed similar distribution to those in the spring (Fig. 2F, 2G). Temperature was higher than that of spring, and salinity was on the contrary (Table 2). Compared to that of spring, nutrient average concentration was higher in summer (Table 2). In surface water, the spatial distributions of DIN and $\mathrm{SiO}_{3}{ }^{2-}-\mathrm{Si}$ were similar to that in spring (Fig. $2 \mathrm{H}, 2 \mathrm{~J}$ ). $\mathrm{PO}_{4}{ }^{3-}-\mathrm{P}$ concentration decreased from northwest to southeast, with the highest mean in Tong'an water and the lowest in Dadeng water (Fig. 2I, Table 2). In bottom water, nutrient concentrations were lower and showed similar spatial distribution with those in surface water.

\section{B. Spatial and Seasonal Distribution of Total and Size-fractionated Chla}

Total and size-fractionated Chla concentrations, different size proportions to total Chla concentration in spring and summer cruises were summarized in Fig. 3-4.
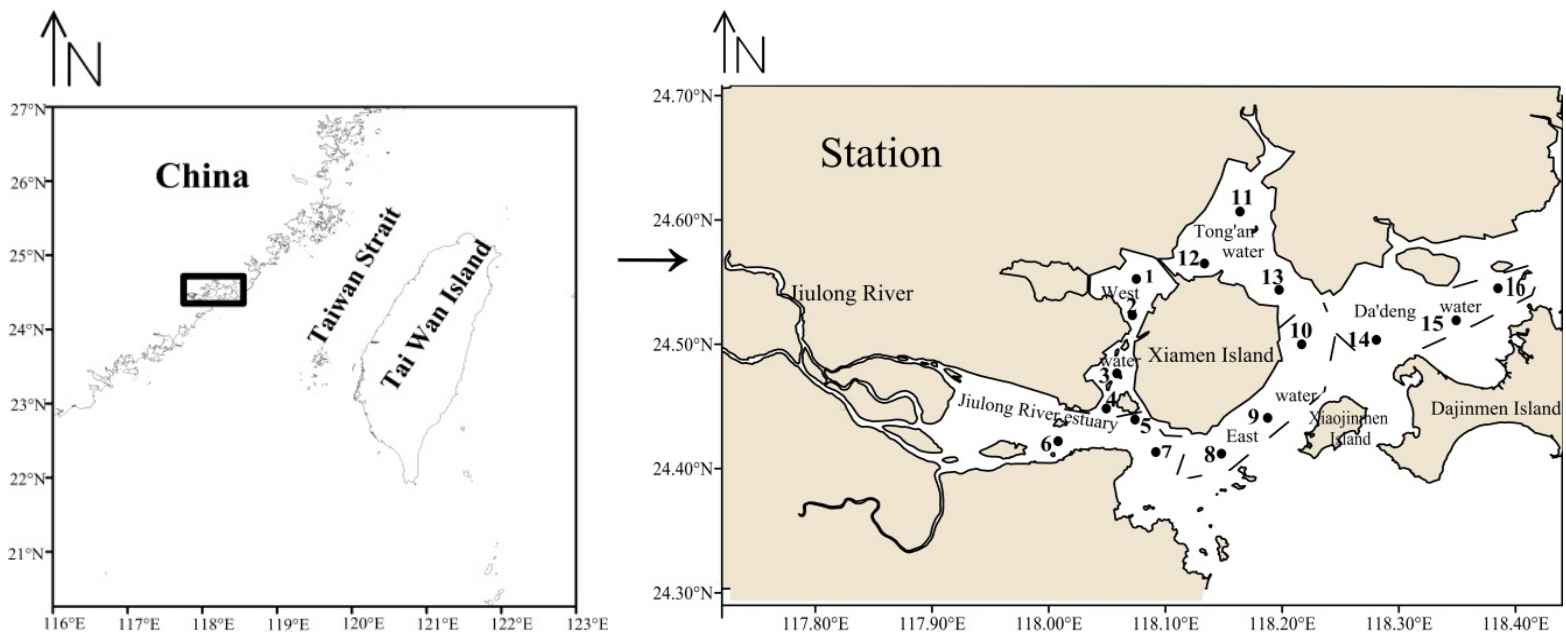

Figure 1. Locations of sampling sites in Xiamen Bay in spring and summer cruises in 2015.
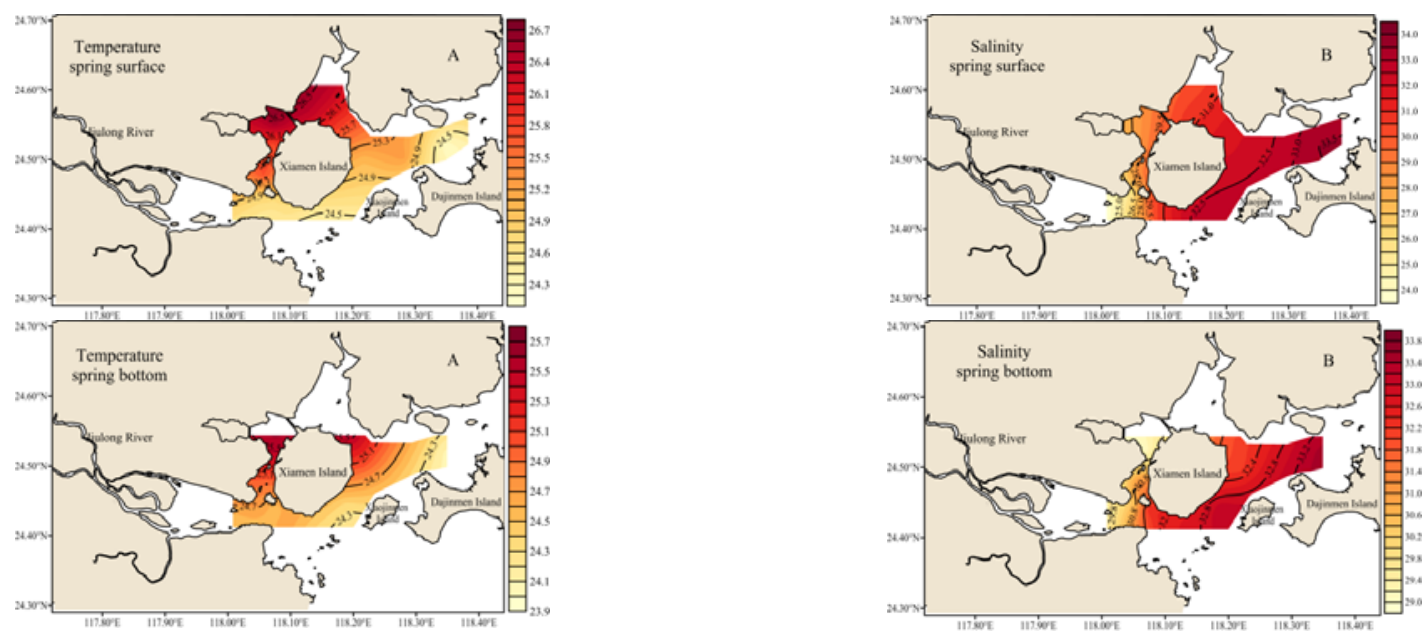

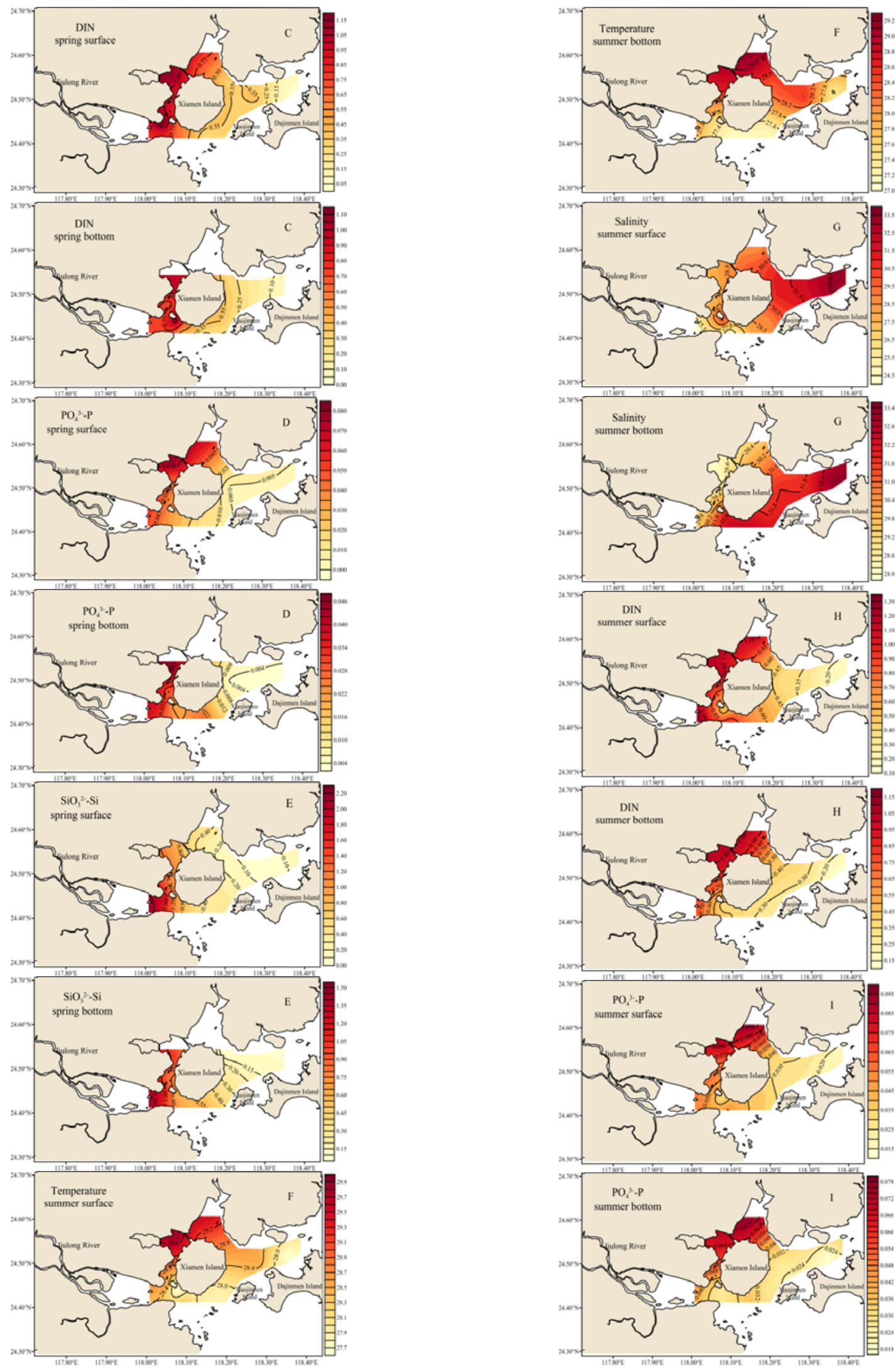


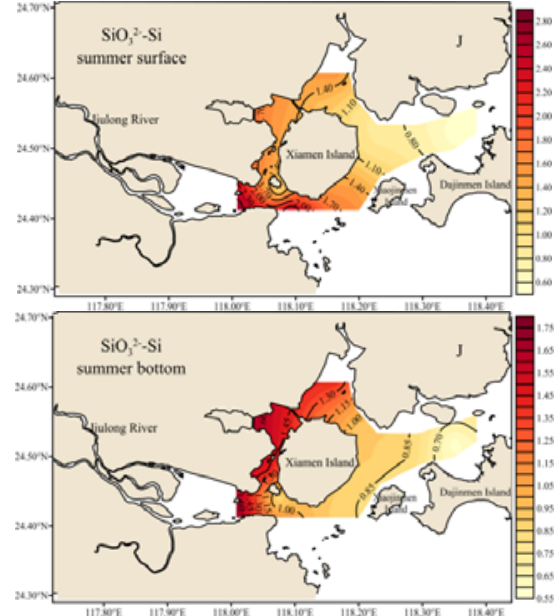

Figure 2. Spatial distributions of temperature, salinity and nutrient concentrations in Xiamen Bay in spring and summer cruises (A - E: spring; F - J: summer, lack of the data of Station 2, 11-12, 14, 16 in bottom water in spring cruise).

In spring cruise, in surface water, total Chla concentration was $1.67 \mu \mathrm{g} / \mathrm{L}-5.00 \mu \mathrm{g} / \mathrm{L}$, increasing from west to east (Fig. 3A, Table 3). The highest mean was in low nutrient Da'deng water (Table 3). Micro- and pico- Chla concentration showed higher in east than that in west, and the highest mean of pico- and micro- in Tong'an water and Da'deng water respectively. The lowest micro- was in West water West water (Fig. 3B, 3D). The highest nano- Chla concentration was in the high nutrient Jiu'- long River Estuary (Fig. 3C, Table 3). In bottom water, total Chla concentration was $1.35 \mu \mathrm{g} / \mathrm{L}-4.87 \mu \mathrm{g} / \mathrm{L}$ and showed the similar trend to that of surface water (Fig. 3A, Table 3 ). Size-fractionated phytoplankton Chla showed similar distribution with that of surface water (Fig. 3B-3D). Surface total Chla concentration was higher than that of bottom water (Table 3).

Nano-phytoplankton was the dominated contributor, followed by micro- and pico- in this study area (Fig. 4A-4B, Table 3). In surface water, micro- proportion was higher in east than in west. The highest proportion was in Da'deng water and the lowest was in West water. Pico- proportion showed similar distribution with micro-, with the highest

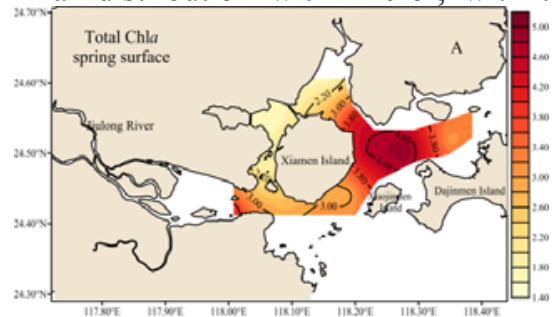

mean in Tong'an water (Fig. 4A, Table 3). However, nanoproportion was higher in west than in east (Fig. 4A). The highest nano- proportion was in high nutrient West water (Fig. 4A). Phytoplankton size index was 12.2-35.4, increasing from west to east (Fig. 3E). The highest mean was in Da'deng water and the lowest was in West water (Table 3). In bottom water, distribution of size-fractionated phytoplankton proportion was similar to that in surface water (Fig. 4B). SI was 7.2-25.9, showing similar distribution with that of surface water (Fig. 3E)

In summer cruise, total Chla concentration has no obvious regular distribution in surface water. Total Chla concentration ranged from $2.07 \mu \mathrm{g} / \mathrm{L}-7.99 \mu \mathrm{g} / \mathrm{L}$, averaging $3.26 \mu \mathrm{g} / \mathrm{L}$ (Table 4). The highest mean was in West water and the lowest mean was in the Jiu'long River Estuary (Fig. 3F, Table 4). Pico-, nano- and micro- Chla concentration appeared the highest mean in West water (Fig. 3G-3I, Table 4). Pico- Chla decreased from north to south (Fig. 3G). Nano- Chla showed the lowest value in the Jiu'long River Estuary (Fig. 3H). In bottom water, total Chla concentration was $1.35 \mu \mathrm{g} / \mathrm{L}-4.87 \mu \mathrm{g} / \mathrm{L}$ and showed a similar trend to that in surface water (Fig. 3F, Table 4). Size fractionated phytoplankton Chla concentration was similar to that in surface water. Comparing with that in spring, the mean of nano- Chla concentration was higher, especially in nutrient-rich West water, but the mean of micro- Chla concentration was lower in this study area.

Nano-phytoplankton was still the dominated contributor in study area (Fig. 4C, 4D, Table 4). In surface water, the highest of nano- and micro- proportion was respectively in East water and in the Jiu'long River Estuary (Fig. 4C). Phytoplankton size index was 5.3-20.5, with the highest value in the Jiu'long River Estuary (Table 4). In bottom water, the highest mean of micro- was in West water, and that of nano- was in the Jiu'long River Estuary (Fig. 4D). SI was 6.4-21.1, with the highest value in West water (Table 4). Pico- proportion showed the highest mean in Tong'an water both in surface and bottom water, which was similar to that of spring (Fig. 4C, 4D). Compared with that in spring, microproportion was lower, whereas, nano- was on the contrary. SI was lower in summer.

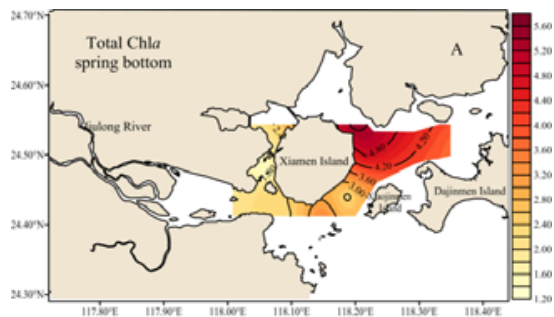



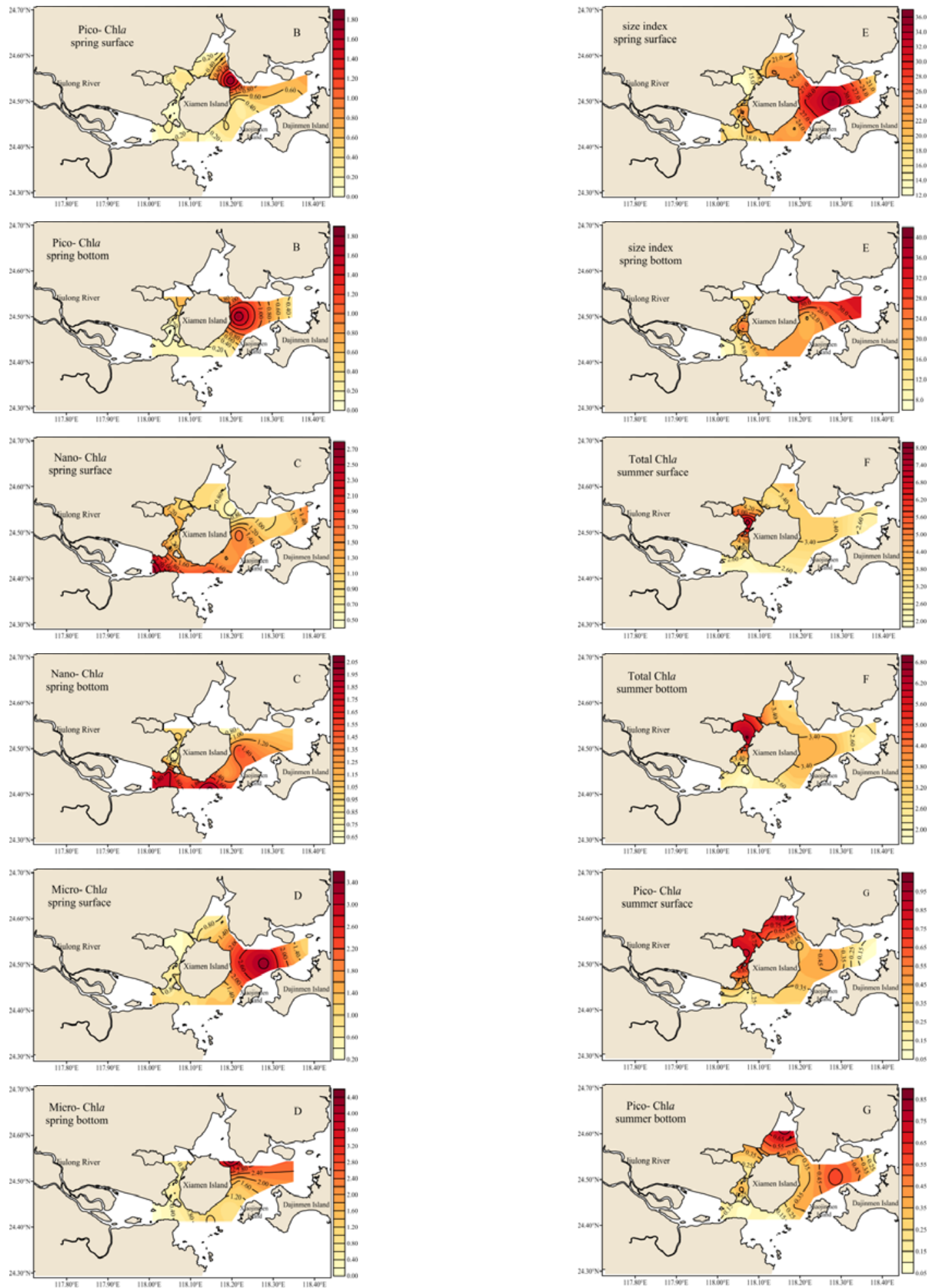

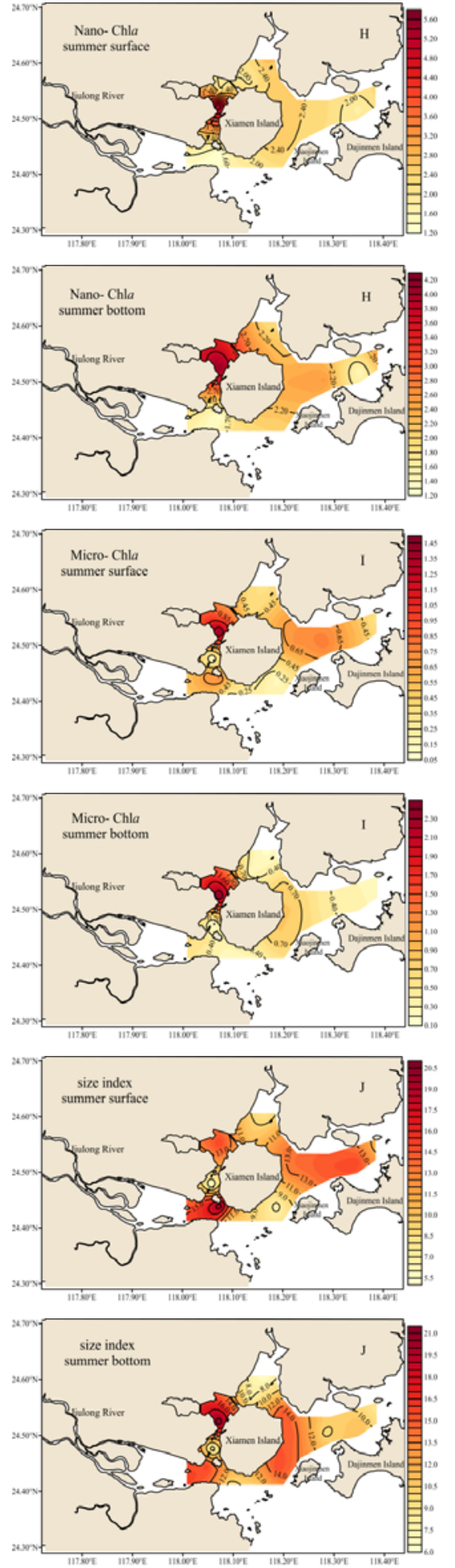

Figure 3. Spatial distributions of total Chla concentration and size index in spring and summer cruises in Xiamen Bay (lack of the data of Station 2, 11-12, 14, 16 in bottom water in spring cruise, A - E: spring; F - I: summer)
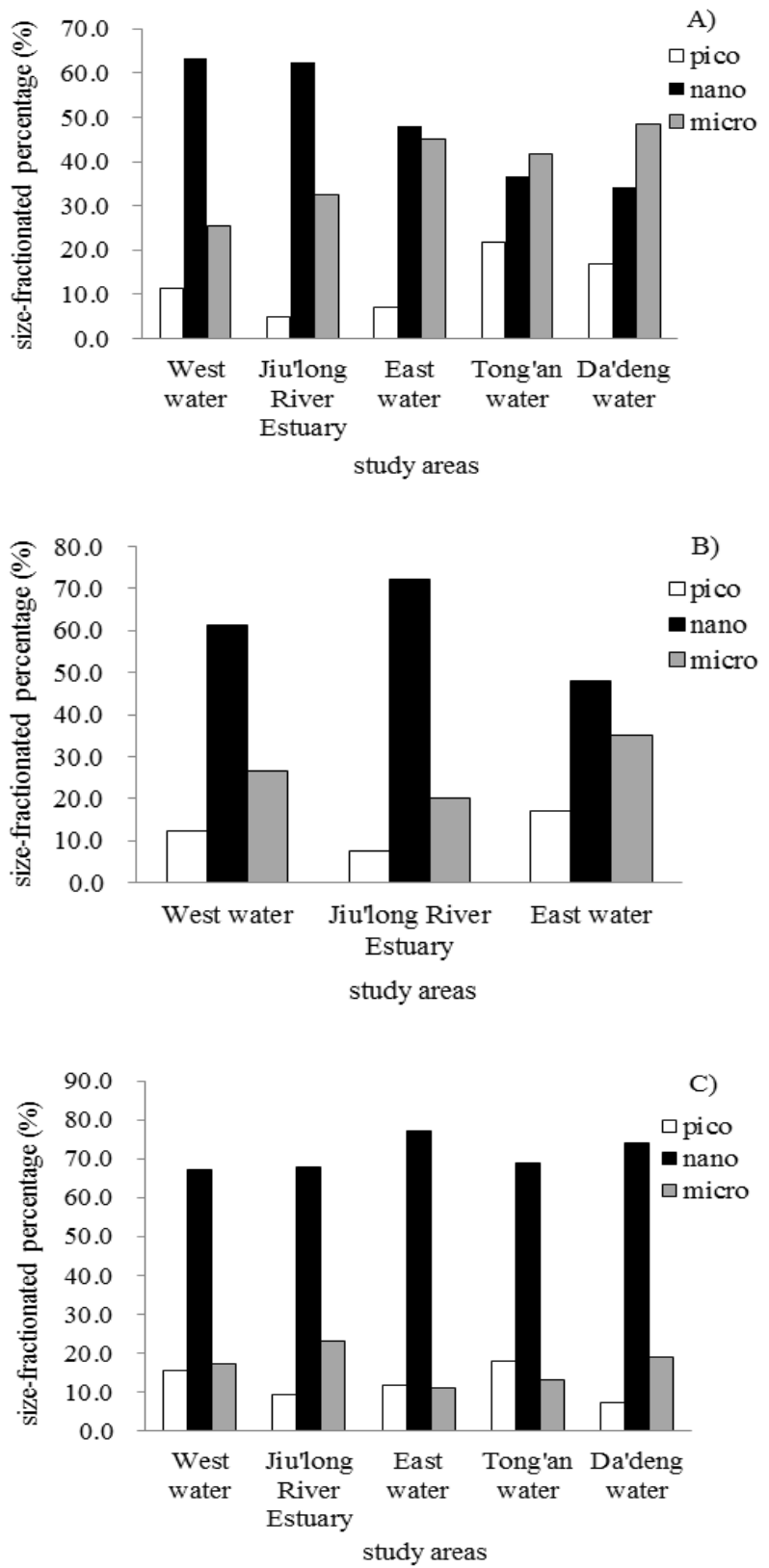


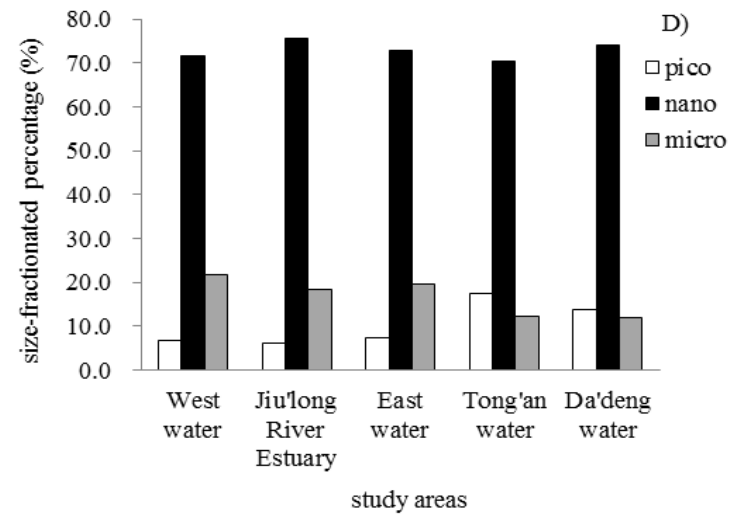

Figure 4. Spatial distributions of size-fractionated phytoplankton average proportions in spring and summer cruises (A: spring surface; B: spring bottom; C: summer surface; D: summer bottom, lack of the data of the

Tong'an water and Da'deng water in bottom water in spring cruise).

\section{DISCUSSIONS}

\section{A. Total Chla and Its Relationship with Environmental Factors}

This investigation revealed a significant seasonal and spatial variation of total Chla concentration. In spring, the highest value of total Chla concentration was in oligotrophic Da'deng water, showing a negative relationship with DIN and $\mathrm{PO}^{3-}-\mathrm{P}$ concentrations. It might be due to that zooplankton especially copepod grazing pressure was stronger in west area than that in east area. Some previous study discovered the similar result in the Pearl River Estuary [29]. Unlikely to that of spring, the highest total Chla concentration appeared in nutrient-rich and low salinity West water in summer, similar to the results of previous studies in Xiamen Bay [31], [32], [33]. The probable reason was that high nutrient and poor water exchange with oceanic water appeared in West water. Zhou et al. (2012) also observed that the highest Chla concentration occurred at intermediate salinities $(\sim 20-30)$ region with sufficient nutrients in the Yangtze River Estuary in summer [11]. Total Chla concentration was higher in summer than that of spring, because that larger Jiu'long River runoff with high nutrient strongly influenced on the waters in Xiamen Bay in summer than in spring. Based on correlation analysis, total Chla concentration showed no obvious relationship with nutrient in high phytoplankton biomass water. Cao et al. (2005) also reported similar result [33].

Besides nutrient, temperature and salinity were important cological factors in oceanic and coastal water [20]. A positive correlation between temperature and total Chla concentration was found in summer. In bottom water, total Chla concentration was lower than that of surface water, and showed a negative correlation with salinity. Zhang et al. (2015) also observed that sediment retention, temperature increased, and salinity decreased as well as reduction in water exchanges, induced obvious increases in cell density and phytoplankton Chla in Hangzhou Bay [38].

\section{B. How Environmental Factor Influence Size Structure of Phytoplankton Community}

Size-fractionated Phytoplankton Chla concentration and their contribution in Xiamen Bay showed a large seasonal fluctuation. In spring, the highest pico- Chla concentration was around low nutrient Da'deng water, and pico- proportion was higher in east than that in west. Huang et al. (2006) also reported that pico-phytoplankton was dominated in the oligotrophic Central Yellow Sea [39]. Raven et al. (1998) found that pico-phytoplankton had a higher capacity for nutrient acquisition in low nutrient waters due to their higher surface-to-volume ratios and small diffusion boundary [40]. The high nano- Chla concentration and proportion appeared in the Jiu'long River Estuary, similar with preceding result in autumn 2014 from Fu [41]. It showed a positive correlation between nano- proportion and nutrient in surface water (Table 5). Furthermore, a positive correlation of nano- Chla concentration with $\mathrm{SiO}_{3}{ }^{2-}-\mathrm{Si}$ and $\mathrm{Si} / \mathrm{N}$ was appeared in surface water. In previous studies, Skeletonema costatum was the dominant species in Xiamen Bay [25], [42]. It indicated that high nutrient from Jiu'long river runoff played significant roles on nano-phytoplankton growth in the bay. In nutrient-rich West water, nano- proportion showed a high value, whereas micro- proportion was low and showed a negative correlation with nutrient in this study area (Table 5). Chen et al. (2010) also reported that phytoplankton community showed smaller trend with nutrient enrichment in Xiamen Bay from 1950s to 2000s [25]. Some previous study indicated that small size phytoplankton increased whereas large ones decreased under nutrient-rich waters [14]. Wang et al. (2009) reported that higher nutrient concentration accelerated the growth of small diatoms, induced the shift in predominant species from large diatom to small ones in Daya Bay, South China Sea [43]. Yang et al. (2014) reported that smaller size species especially dinoflagellates proportion showed increasing trend in the Changjiang River Estuary and Adjacent Seas during 1950s-2000s [44]. It was considered that small phytoplankton might have filled the niches vacated by the large ones in nutrient-rich water.

In summer, different from spring, pico- Chla concentration and proportion showed the positive correlations with DIN and $\mathrm{PO}_{4}{ }^{3-}-\mathrm{P}$ concentrations. The previous research also found the similar result in autumn of 2014 in Xiamen Bay [41]. It might be relative to increase of nutrient and temperature in summer. Qiu et al. (2010) observed that increased nutrient also led to increase of pico-phytoplankton in the Pearl River Estuary [16]. NanoChla concentration and proportion were higher than those in most stations in spring, whereas micro- showed lower. Nanoproportion has the dominant position. The positive correlation between nano- proportion and $\mathrm{Si} / \mathrm{N}$ was observed in surface water (Table 6). Zhang et al. (2015) reported that $\mathrm{Si} / \mathrm{N}$ was the main variable associated with algal assemblage in Hangzhou Bay by Canonical correspondence analysis (CCA) [38]. It can be concluded that small (pico- and nano-) phytoplankton have a stronger growth capacity than large ones with temperature and nutrient increased in summer. In the Jiu'long River Estuary, compared with that of spring, 
nano- Chla concentration showed lower value in summer. It might be due to that water strongly mixed and its residence time was so short that nano-phytoplankton could not growth well.

In spring, negative correlation of SI with nutrient concentrations and the lowest mean of SI in West water. Comparing with that of spring, SI showed lower mean in summer. To some extent, these results confirmed that size structure of phytoplankton community became smaller in higher nutrient and warmer water, which was consistent with previous reports [25], [14]. In this study, according to the data of environmental factors, the vertical mixing of water body is uniform in Xiamen Bay. Therefore, the response of size-fractionated phytoplankton in bottom water to environmental factors was similar with that of surface water.

Previous studies reported that small phytoplankton had strong growth ability in high temperature, while large phytoplankton showed the opposite trend [45], [46], [47]. In this study, statistical analysis indicated that pico- Chla concentration and its proportion showed a positive relationship with temperature in the summer (Table 6). Nanoproportion gained a fairly large share of total Chla in low salinity area and showed a negative relationship with salinity in surface water in spring (Table 5). Li et al. (2013) also reported that nano-phytoplankton dominated in low salinity water in the Pearl River Estuary [29]. Salinity and temperature were also important factors in phytoplankton growth. Compared with historical results in Table 7, nanoproportion increased, but micro- was on the contrary with nutrient enrichment in summer. Fu et al. (2016) also reported that nano- proportion is higher in nutrient-rich waters (Tong'an water and the Jiu'long River Estuary) than that in low nutrient waters (Da'deng water) in autumn in Xiamen Bay [41]. The changes of phytoplankton community were hypothesized to reflect the combined influences of eutrophication, climate change and large-scale aquaculture [48]. It may be concluded that nano-phytoplankton had a competitive superiority with nutrient enrichment in Xiamen Bay.

\section{REFERENCES}

[1] J. E. Cloern and R. Dufford, "Phytoplankton Community ecology: Principles applied in San Francisco Bay," Marine Ecology Progress Series, vol. 285, Jan. 2005, pp.11-28, doi.org/10.3354/ meps285011.

[2] R. B. Domingues, A. Barbosa and H. Galvao, "Constraints on the use of phytoplankton as a biological quality element within the Water Framework Directive in Portuguese waters," Marine Pollution Bulletin, vol. 56, Jul. 2008, pp. 1389-1395, doi: 10.1016/j.marpolbul.2008.05.006

[3] M. Garmendia, M. Revilla, J. Bald, J. Franco, A. Laza-Martínez, E. Orive, S. Seoane, V. Valencia and A. Boija, "Phytoplankton communities and biomass size structure (fractionated chlorophyll"a") along trophic gradients of the Basque coast (northern Spain)," Biogeochemistry, vol. 106, 2011, pp. 243-263, doi:10.1007/s10533-010-9445-2.

[4] L. Legendre and F. Rassoulzadegan, "Food-web mediated export of biogenic carbon in oceans: hydrodynamic control," Marine Ecology Progress Series, vol. 145, Dec. 1996, pp. 179-193, doi: 10.3354/meps 145179 .

[5] P. G. Falkowski and M. J. Oliver, "Mix and match: How climate selects phytoplankton," Nature Review Microbiology, vol. 5, Oct. 2007, pp. 813-819, doi: 10.1038/nrmicro1751.

[6] Z. V. Finkel, J. Beardall, K. J. Flynn, A. Quigg, T. A. V. Rees and J.
A. Raven, "Phytoplankton in a changing world: Cell size and elemental stoichiometry," Journal of Plankton Research, vol. 32, Oct. 2009, pp. 119-137, doi: 10.1093/plankt/fbp098.

[7] P. Cermeño, E. Marañón, V. Perez, P. Serret, E. Fernández and C. G. Castral, "Phytoplankton size structure and primary production in a highly dynamic coastal ecosystem (RíadeVigo, NW-Spain): Seasonal and short-time scale variability," Estuary, Coastal Shelf Science, vol. 67, Jan. 2006, pp. 251-266, doi: 10.1016/jcsr.2008.11.013.

[8] M. ZH. Fu, Z. L. Wang, Y. Li, R. X. Li, P. Sun, X. H. Wei, X. ZH. Lin and J. S. Guo, "Phytoplankton biomass size structure and its regulation in the Southern Yellow Sea (China): Seasonal variability," Continental Shelf Research, vol. 29, Aug. 2009, pp. 2178-2194, doi: 10.1016/j.csr. 2009.08.010.

[9] I. Siokou-Frangou, U. Christaki, M. G. Mazzocchi, M. Montresor, D. Ribera, M. Alcala, D. Vaque and A. Zingone, "Plankton in the open Mediterranean Sea: A review," Biogeosciences, vol. 6, May 2010, pp. 11187-11293, doi: 10.5194/bg-7-1543-2010.

[10] H. O. María, C. D. Alejandra, G. Rocío, M. C. Beatriz and M. Emilio, "Effect of environmental forcing on the biomass, production and growth rate of size-fractionated phytoplankton in the central Atlantic Ocean,” Journal of Marine Systems, vol. 88, May 2011, pp. 203-213, doi: 10.1016/j.jmarsys.2011.04.007.

[11] W. H. Zhou, K. D. Yin, A. M. Long, H. Huang, L. M. Huang and D. D. $\mathrm{Zhu}$, "Spatial-temporal variability of total and size-fractionated phytoplankton biomass in the Yangtze River Estuary and adjacent East China Sea coastal waters, China," Aquatic. Ecosystem Health \& Management, vol. 15, 2012, pp. 200-209, doi: 10.1080/14634 988.2012.688727.

[12] N. ZH. Jiao, "The ecological processes and sustainable development in the Bay," Beijing: Science Press, 2001, pp. 241-253(in Chinese).

[13] A. Zingone, D. Sarno, R. Siano and D. Marino, "The importance and distinctiveness of small-sized phytoplankton in the Magellan Straits," Polar Biology, vol. 34, Sep. 2011, pp.1269-1284, doi: 10.1007/s00300-010-0937-2.

[14] S. Suikkanen, S. Pulina, J. Engstöm-öst, M. Lehtiniemi, S. Lehtinen and A. Brutemark, "Climate Change and Eutrophication Induced Shifts inNorthern Summer Plankton Communities," PloS One, Vol. 8, Jun. 2013, pp. 1-10, doi: 10.1371/journal.pone.0066475.

[15] F. P. Wilkerson, A. M. Lassiter, R. C. Dugdale, A. Marchi and V. E. Hogue, "The phytoplankton bloom response to wind events and upwelled nutrients during the CoOP WEST study," Deep-Sea Research II, vol. 53, Nov. 2006, pp. 3023-3048, doi: 10.1016/j.dsr2.2006.07.007.

[16] D. J. Qiu, L. M. Huang, J. L. Zhang and S. J. Lin, "Phytoplankton dynamics inand near the highly eutrophic Pearl River Estuary, South China Sea," Continental Shelf Research, vol. 30, Nov. 2009, pp. 177-186, doi: 10.1016/j.csr.2009.10.015.

[17] K.M. Hilligsøe, K. Richardson, J. Bendtsen, L. L. Sørensen, T. G. Nielsen and M. M. Lyngsgaard, "Linking phytoplankton community size composition with temperature, plankton food web structure and sea-air $\mathrm{CO}_{2}$ flux," Deep-Sea Research I. vol. 58, Jun. 2011, pp.826-838, doi: 10.1016/j.dsr.2011.06.004.

[18] X. Liu, B. Q. Huang, Q. Huang, L. Wang, X. B. Ni, Q. SH. Tang, S. Sun, H. Wei, S. M. Liu and CH. L. Li, "Seasonal phytoplankton response to physical processes in the southern Yellow Sea," Journal of Sea Research, vol. 95, Oct. 2014, pp. 45-55, doi: 10.1016/j.seares. 2014. 10.017

[19] A. Andersson, P. Haecky and A. Hagström, "Effect of temperature and light on the growth of micro- nano- and pico-plankton: impact on algal succession," Marine Biology, vol. 120, Apr. 1994, pp. 511-520, doi: 10.1007/BF00350071.

[20] N. R. S Agawin, C. M. Duarte and S. Agustí, "Nutrient and temperature control of the contribution of picoplankton to phytoplankton biomass and production," Limnology Oceanography, vol. 45, May 2000, pp. 591-600, doi:10.2307/2670 836.

[21] CH. M. Deng, ZH. G. Yu, P. Yao, H. T. Chen and CH. Y. Xue, "Phytoplankton size structure and environmental factors in the Southern Yellow sea and East Sea of China," Periodical of ocean university of China, vol. 38, Sep. 2008, pp.791-798(in Chinese).vol. 109, Nov. 2004, pp. C11010, doi: 10.1029/2004J C002419.

[22] R. Riegman and A. A. M. Noordeloos, "Size-fractionated uptake of nitrogenous nutrients and carbon by phytoplankton in the North Sea 
during summer 1994," Marine Ecology Progress Series, vol. 173, Nov. 1998, pp. 95-106, doi: 10.3354/meps173095.

23] H. SH. Hong, P. Y. Wang and ZH. Zhang, "Preliminary study of wate requirement in Jiu'long River ecological environment," Journal of Xiamen University (Natural science), vol. 45, Nov. 2006, pp. 819-823(in Chinese).

[24] Y. B. Zhang and H. Lin, "Research and forecasting model of long-term changes of nutrient content in the West water of Xiamen Bay," Journal of Oceanography in Taiwan Strait, vol. 27, Nov. 2008, pp. 500-503(in Chinese).

[25] B. H. Chen, ZH. H. Xu, Q. L. Zhou, CH. P. Chen, Y. H. Gao, SH. Y. Yang and W. D. Ji, "Long-term changes of phytoplankton community in Xiagu waters of Xiamen, China," Acta Oceanologica Sinica, vol. 29, Apr. 2010, pp. 104-114, doi: 10.1007/s00343-014 -3214-3.

[26] H. Lin and Y. B. Zhang, "Study on the changes of eutrophication in Xiamen Bay," Journal of Oceanography in Taiwan Strait, vol. 27, Aug. 2008, pp. 347-355(in Chinese).

[27] Z. L. Shen, "Historical changes in nutrient structure and its influences on phytoplankton composition in Jiaozhou Bay," Estuarine, Coastal Shelf Resreach, vol. 52, Apr. 2000, pp. 211-224, doi: 10.1006/ecss.2000.0736.

[28] X. P. Huang, L. M. Huang and W. Z. Yue, "The characteristics of nutrients and eutrophication in the Pearl River estuary, South China,' Marine Pollution Bulletin, vol. 47, Feb. 2003, pp. 30-36, doi 10.1016/S0025-326X(02)00474-5.

[29] L. Li, SH. Lu, T. Jiang and X. Li, "Seasonal variation of size-fractionated phytoplankton in the Pearl River estuary," Chinese Science Bulletin, Vol. 58, Jul. 2013, pp. 2303-2314, doi: 10.1007/s11434-013-5823-1.

[30] Y. Peng, Z. G. Yu, C. M. Deng, S. X. Liu and Y. Zhen, "Spatial-temporal distribution of phytoplankton pigments in relation to nutrient status in Jiaozhou Bay, China," Estuarine, Coastal Shelf Science, vol. 89, Jul. 2010, pp. 234-244, doi: 10.1016/j.ecss.2010.07. 003.

[31] Y. H. Gao, D. X. Jin and Y. D. Cheng, "The distribution and function of micro-plankton Chlorophyll a in Xiamen harbor," Chinese Journa of Oceanology and Limnology, vol. 25, Jan. 1994, pp. 87-93(in Chinese).

[32] H. SH. Hong and B. Q. Huang, "Photosynthetic rate and biomass of size-fractionated phytoplankton in west water of Xiamen Bay in autumn," Journal of Xiamen University (Natural Science), vol. 33(sup.), Jun. 1994, pp. 13-16(in Chinese).

[33] ZH. R. Cao, B. Q. Huang, Y. Liu, H. SH. Hong and T. G. Xie, "The distribution characteristics of size-fractionated phytoplankton chlorophyll a concentration in Xiamen Bay," Journal of Oceanography in Taiwan Strait, vol. 24, Nov. 2005, pp. 494-501 (in Chinese).

[34] B. H. Chen, CH. P. Chen, J. M. Chen, Y. Gao, H. Lin, H. N. Huang, W. D. Ji and Y. H. Gao, "Changes of nutrients concentration and structure, and its influence on phytoplankton community in Xiamen Sea," Journal of Oceanography in Taiwan Strait, vol. 31, May 2012, pp. 246-253(in Chinese).

[35] J. M. C. N. Sieburth, V. Smetacek and J. Kenz, "Pelagic ecosystem structure: heterotrophic compartments of the plankton and their relationship to plankton size fraction," Limnology Oceanography, vol. 23, Nov. 1978, pp. 1256-1263, doi: 10.4319/lo.1978.23.6.1256.

[36] T. R. Parsons and Y. C. M. A. Maita, "Manual of Chemical and Biological Methods for Seawater Analysis," Oxford: Pergamin Press, vol. 107-109, Apr. 1984, pp. 115-122.

[37] A. Bricaud, H. Claustre, J. Ras and K. Oubelkheir, "Natural variability of phytoplanktonic absorption in oceanic waters: influence of the size structure of algal populations," Journal of Geophysical Research, vol 109, Nov. 2004, pp. C11010 doi:10.1029/2004JC002419.

[38] Y. X. Zhang, J. Yu, ZH. B. Jiang, Q. Wang and H. Wang, "Variations of Summer Phytoplankton Community Related to Environmental Factors in a Macro-Tidal Estuarine Embayment, Hangzhou Bay, China," Journal Ocean University China, vol. 14, Oct. 2015, pp. 1025-1033, doi: .1007/s11802-015-24 83-6.

[39] B. Q. Huang, Y. Liu, J. X. Chen, D. ZH. Wang, H. SH. Hong, L. F. Huang, Y. Lin and H. Wei, "The spatial and temporal distribution of phytoplankton biomass and size structure in East Sea and Yellow Sea,' Acta Oceanologica Sinica, vol. 28, Mar. 2006, pp. 157-164(in Chinese).
[40] J. A. Raven, "The twelfth Tansley Lecture. Small is beautiful: the picophytoplankton," Functional Ecology, vol. 12, Aug. 1998, pp. 503-513, doi/10.1046/j.1365-2435.1998.00233.x/epd f.

[41] T. T. Fu, B. H. Chen, W. D. Ji, H. Z. Chen, W. F. Chen, X. Dong, W. M. Kuang, J. M. Chen, J. G. Wang and H. Lin, "Size structure of phytoplankton community and its response to environmental factors in Xiamen Bay, China," Environmental Earth Science, vol. 75, Apr. 2016, pp. 734, doi: 07/s12665-016-5552-2.

[42] D. X. Jin, "Plankton quantified research of Xiamen harbor in 1954," Journal of Xiamen University (Natural Science), vol. 5, 1955, pp. 17-30(in Chinese).

[43] ZH. H. Wang, J. G. Zhao, Y. J. Zhang and Y. Cao, "Phytoplankton community structure and environmental parameters in aquaculture areas of Daya Bay, South China Sea," Journal Environmental Science, vol. 21, Mar. 2009, pp.1268-1275, doi: 1016/S100 1-0742(08) 62414 -6 .

[44] S. H. Yang, X. R. Han, CH. S. Zhang, B. Y. Sun, X. L. Wang and X. Y. Shi, "Seasonal Changes in Phytoplankton Biomass and Dominant Species in the Changjiang River Estuary and Adjacent Seas: General Trends Based on Field Survey Data 1959-2009," Journal Ocean University China, vol. 13, Dec. 2014, pp. 926-934, doi: .1007/s11802-014-2515-7.

[45] L. S. Murphy and E. M. Haugen, "The distribution and abundance of phototrophic ultraplankton in the North Atlantic," Limnology Oceanography, vol. 30, Jan. 1985, pp. 47-56, doi: 0.4319/lo.1985.30.1.0047

[46] X. G. Morán, L. U. Ángel and C. D. Alejandra, "Increasing importance of small phytoplankton in a warmer ocean," Global Change Biology, vol. 16, May 2010, 1137-1144, doi: 10.1111/j.1365-2486.2009.01960.x.

[47] E. A. Mousing, M. Ellegaard and K. Richardson, "Global patterns in phytoplankton community size structure-evidence for a direct temperature effect," Marine Ecology Progress Series, vol. 497, 2014, pp. 25-38, doi: 10.3354/meps 10583 .

[48] D. Y. Liu, J. Sun, J. Zhang and G. S. Liu, "Response of the Diatom flora in Jiaozhou Bay, China to environmental changes during the last century," Marine Micropaleontology, vol. 66, Feb. 2008, pp. 279-290, doi: 10.1016/j.marmicro.2007.10.007. 